\title{
Islamic Microfinance Service Quality and Its Impact on Yogyakarta Customers' Satisfaction and Loyalty
}

\author{
Prastyono Putro Pangarso ${ }^{1 *}$, Sumadi $^{2}$ \\ ${ }^{1}$ Program Pascasarjana Fakultas Ekonomi, Universitas Islam Indonesia,Indonesia. \\ ${ }^{2}$ Fakultas Ekonomi, Universitas Islam Indonesia, Yogyakarta, 55283 Indonesia.
}

Email: sumadi@uii.ac.id

\begin{abstract}
.
The purpose of this study is to examine the effect of service quality and religiosity on customer satisfaction and loyalty of Islamic Microfinance (KSPPS) in Yogyakarta. The research method uses a qualitative approach. The population in this study were all KSPPS customers in Yogyakarta. Samples were taken by 150 customers from 8 KSPPS using purposive sampling techniques. The analytical tool used for testing hypotheses in this study uses Structural Equation Model (SEM) analysis with the Analysis Moment of Structure (AMOS) software application. The results of this study indicate that customer satisfaction has a positive and significant effect on customer loyalty. Religiosity has a positive and significant effect on customer satisfaction. Religiosity has a positive but not significant effect on customer loyalty. Service Quality has a positive and significant effect on customer satisfaction. Quality of service has a positive and significant effect on customer loyalty.
\end{abstract}

Keywords:Islmaic Microfinance, Service Quality, Religiosity, Customer Satisfaction, Customer Loyalty.

\section{INTRODUCTION}

Marketing management in the modern era has experienced a shift from a strategy that was initially oriented towards creating sales to being customer-oriented. Customer satisfaction needs to be considered by the company because it will have an impact on sales performance. Satisfied customers will buyback, and they will tell others about the good experience of the product[1].

Customer loyalty is an important aspect that must be considered because it involves the survival of its business and business activities. Loyal customers are generally those who are satisfied with certain products and services, so they have the enthusiasm to introduce these products and services to anyone they know voluntarily. Kotler and Keller stated that satisfaction is someone's happy or disappointed feelings that arise after comparing the performance (or results) of the product thought to the expected performance [2]. In other words, someone will feel satisfied if the results obtained at least can meet their expectations, while someone feels dissatisfied if the results obtained cannot meet their expectations. Satisfaction felt by someone will have an impact on one's behavior which will result in reuse continuously or adventurous so that loyalty is formed. 
Religiosity in religion can contribute to providing services and reflecting on the company's identity. Religiosity is manifested in various aspects of human life. Religious activities do not only occur when someone performs special worship behavior but also when carrying out other life activities. And not only those related to activities that can be seen by the eye but also those activities that are not visible and occur in one's heartstrings. Religiosity is a belief in God accompanied by a commitment to follow the principles that are believed to be set by Allah[3].In providing services, all related activities must be based on compliance with sharia that is full of moral and ethical values[4].

Good service to customers will be able to create a positive image and impression of the company. Good service encourages customer interest to reuse these services to create loyalty. One way to make a difference from a service company is to provide services of higher quality than its competitors consistently. The key is to meet or exceed the quality expectations of the target customer service [5]. According to Parasuraman, et.al that there are five dimensions of service quality determinants, namely reliability, responsiveness, assurance, empathy, and tangibility[6].

This study aims to examine the effect of service quality and religiosity in relation to customer satisfaction and loyalty in Islamic microfinance institutions. The research will be conducted at KSPPS located in Yogyakarta. Previous studies of service satisfaction with customer loyalty [7], [8], [9], [10], [11]. Research The effect of religiosity on customer satisfaction was carried out by [12] dan [13]. Furthermore, research on the effect of religiosity on customer loyalty was carried out [14] and [15]. While the effect of service quality on customer satisfaction is carried out [8], [7], [16], [17].

Some previous studies as mentioned above, in general, the discussion shows different results. So it is necessary to have the latest research related to this topic with the latest and most recent KSPPS data and context. This is where the urgency of this research is at the same time the reason why this research is important. Based on the above problems, the framework can be explained in the following figure:

Fig 1.Therotical Model

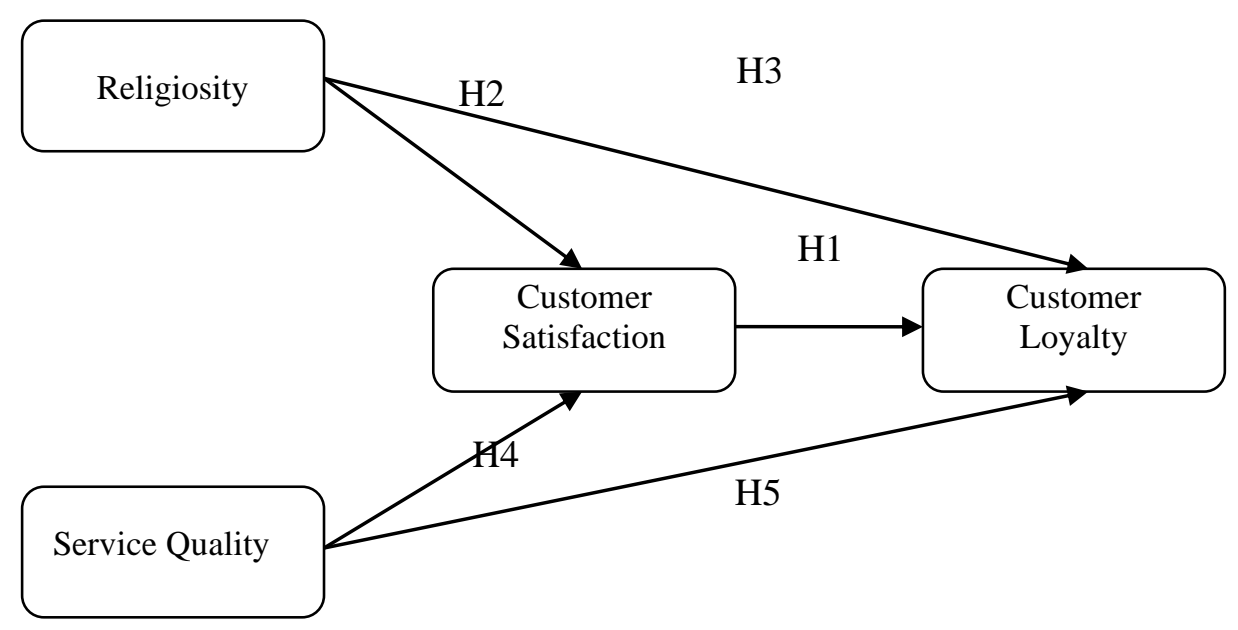




\section{METHODS}

The research method uses a qualitative approach.The population in this study were all KSPPS financing customers in Yogyakarta. Samples were taken by 150 customers from 8 KSPPS using purposive sampling techniques. The research instrument used a questionnaire that was distributed to KSPPS customers. The analytical tool used for testing the hypotheses in this study uses Structural Equation Model (SEM) analysis with the Analysis Moment of Structure (AMOS) software application.

\section{RESULT AND DISCUSSION}

The results of testing analysis with goodness-of-fit criteria show that the model in this study is stated to be in accordance with the suitability criteria which include ChiSquare value, probability, CMIN / DF, GFI, TLI, CFI, and RMSEA on each variable meeting the cut-off standard required value.The final results of the measurement model are explained below:

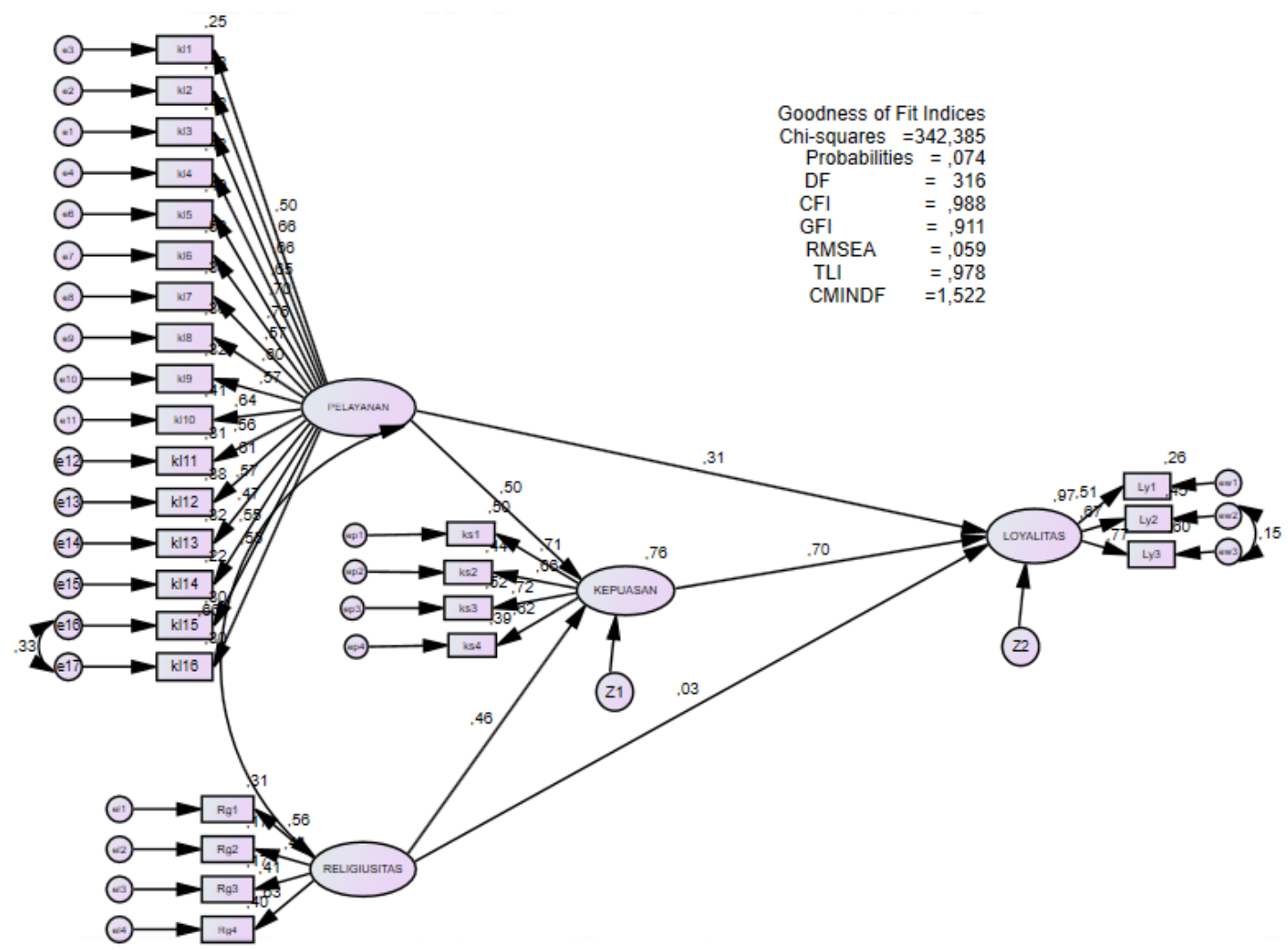

Fig 1. SEM Model 
International Journal Of Science, Technology \& Management

The results of data calculation with the help of Smart PLS 2.0 software show the following:

Table 1. Hypothesis Statistic

\begin{tabular}{|c|c|c|c|c|}
\hline \multirow{2}{*}{ Variables } & \multicolumn{2}{|c|}{ Koef. $\quad$ Regresi Critical } & \multirow{2}{*}{ Sig. } & \multirow[b]{3}{*}{ Signifikan } \\
\hline & Standard & Ratio $\left(t_{h}\right)$ & & \\
\hline $\begin{array}{l}\text { Customer } \quad \text { Satisfaction } \rightarrow \text { Customer } \\
\text { Loyalty }\end{array}$ & $+0,698$ & $+2,561$ & 0,000 & \\
\hline Religiosity $\rightarrow$ Customer Satisfaction & $+0,455$ & $+2,763$ & 0,000 & Signifikan \\
\hline Religiosity $\rightarrow$ Customer Loyalty & $+0,029$ & $+0,153$ & 0,878 & $\begin{array}{l}\text { Tidak } \\
\text { Signifikan }\end{array}$ \\
\hline $\begin{array}{l}\text { Service } \\
\text { Satisfaction }\end{array}$ & $+0,502$ & $+3,631$ & 0,000 & Signifikan \\
\hline Service Quality $\rightarrow$ Customer Loyalty & $+0,308$ & $+1,960$ & 0,000 & Signifikan \\
\hline
\end{tabular}

Source: Processed Data (2018)

Statistical test results show that customer satisfaction has a positive and significant effect on customer loyalty. This can be explained that if Customer Satisfaction has increased, then the increase will also occur in Customer Loyalty. The results of this study are following the results of previous studies conducted by [7]-[9], [16]which suggests that there is a positive and significant influence between customer Satisfaction on Customer Loyalty. The finding of this research is that customer Satisfaction at KSPPS in Yogyakarta is important, so it needs to be maintained and improved considering that customer satisfaction has a great influence on customer loyalty by increasing the quality of service and religiosity of course.

Statistical test results indicate that the variable religiosity has a positive and significant effect on customer satisfaction. This can be interpreted, if religiosity has increased, then customer satisfaction will also increase. The results of this study are consistent with the results of previous studies which suggest that there is a positive and significant influence between religiosity on customer satisfaction[11]-[13].The finding of this research is that religiosity at KSPPS in Yogyakarta is important, so it needs to be maintained and improved considering that Religiosity has a great influence on Customer Satisfaction.

The results of statistical tests indicate that the variable of religiosity has a positive and not significant effect on customer loyalty. This can be explained that the higher the level of religiosity, it will not affect the customer loyalty. The results of this study contradict the results of previous studies which suggested that there was a positive and significant influence between religiosity on customer loyalty[12], [14], [15].This certainly opens the opportunity to be examined again in the future. The findings of this study are that religiosity at KSPPS in Yogyakarta does not directly influence customer loyalty, but is achieved through customer satisfaction first, so that this religiosity needs to be maintained and improved considering that religiosity has a large influence on Customer Satisfaction which will lead to increased Customer Loyalty. This finding also indicates that KSPPS customers in Yogyakarta still do not fully understand Religiosity. The main motive to become a customer is economic 
factors alone. But KSPPS religiosity factor has been able to provide satisfaction to its customers, which indirectly affects the level of customer loyalty.

Statistical test results show that the service quality variable has a positive and significant effect on customer satisfaction. This can be interpreted, if the Quality of Service has increased, then Customer Satisfaction will also increase. The results of this study are in accordance with the results of previous studies conducted by[17], [18], [19]which suggests that there is a positive and significant effect between service quality on customer satisfaction. The findings of this study are that service quality at KSPPS in Yogyakarta is important, so it needs to be maintained and improved considering that service quality has a direct influence on customer satisfaction.

Statistical test results show that Service Quality variable has a positive and significant effect on customer loyalty. This can be interpreted that if the Quality of Service has increased, then customer loyalty will also increase. The results of this study are consistent with previous findings which suggest that there is a positive and significant effect between service quality on customer loyalty. The findings of this study are that service quality at KSPPS in Yogyakarta is important, so it needs to be maintained and improved considering that the Quality of Service has a direct influence on customer loyalty [7], [10], [11].

\section{CONCLUSION}

The conclusions obtained from this study are as follows:

a. Customer Satisfaction and service quality have a positive and significanteffect on Customer Loyalty.

b. Religiosity has a positive and significant effect on customer satisfaction.

c. Religiosity has a positive but not significant effect on customer loyalty.

d. Service Quality has a positive and significant effect on Customer Satisfaction

In conclusion, this initial study provides KSPPS Maintaining customer loyalty with customer satisfaction by improving customer satisfaction which itself can be improved by increasing the quality of service and religiosity.

\section{ACKNOWLEDGMENTS}

The authors are grateful to theFakultas Ekonomi, Universitas Islam Indonesia and KSPPS for providing data and support in this study.

\section{REFERENCES}

[1] G. Kotler \& Armstrong, Principle of Marketing. 1999. $8^{\text {th }}$ Ed., Prentice-Hall, New Jersey.

[2] K. L. Kotler \& Keller,Manajemen Pemasaran 2. 2007.Ed. 12, PT. Index, Jakarta.

[3] S. J. Vitell, 'The Role of Religiosity in Business and Consumer Ethics: A Review of the Literature', J. Bus. Ethics, vol. 90, pp. 155-167, 2009.

[4] L. Othman, A. \& Owen, 'Adapting and Measuring Customer Service Quality (SQ) in Islamic Banks: A Case Study in Kuwait Finance House', Int. J. Islam. Financ. Serv., vol. 3, no. 1, pp. 1-26, 2001.

[5] P. Kotler, Marketing Management Analysis, Planning, Implementation, and Control $9^{\text {th }}$ Ed. 1997, Prentice-Hall, New Jersey.

[6] L. L. Parasuraman, A., Zeithaml, V.A. \& Berry, 'Parasuraman, A., Zeithaml, V.A. \& 
Berry, L.L. (1985). “A Conceptual Model of Service Quality and Its Implications for Future Research', Journal of Marketing., vol. 49, pp. 41-50, 1985.

[7] F. Nurhayati, \& Sukesti, 'Peningkatan Loyalitas Nasabah Bank Syariah Melalui Peningkatan Kualitas Layanan Dan Kepuasan Nasabah Dengan Variabel Religiusitas Sebagai Variabel Moderating (Studi Pada Bank Syariah Di Kota Semarang)', Jurnal Ekonomika vol. 7, no. 2, 2016.

[8] R. B. Zagoto, R., \& Lestari, 'Analisis Pengaruh Kualitas Jasa Perbankan Terhadap Kepuasan Nasabah Pada PT. Bank Mega Syariah Cabang Kota Palembang, Jurnal Manajemen, STIE Multi Data Palembang.', Jurnal Manajemen, STIE Multi Data Palembang, 2010.

[9] A. Nursiana, 'Pengaruh Kualitas Layanan Terhadap Loyalitas Nasabah dengan Intermediasi Kepuasan Nasabah dan Nilai yang Dirasakan Nasabah',Jurnal Ultima Management., vol. 3, no. 1, p. 2011, 2011.

[10] A. \& K. Aloysius, 'Pengaruh Kualitas Pelayanan Terhadap Loyalitas Nasabah Pada Tabungan BTN Batara (Kasus: PT. Bank Tabungan Negara (Persero) Tbk., Cabang Medan, JOM FISIP, 2(2), Oktober 2015.

[11] F. H. N. Mufti Alam Adha, Rofiul Wahyudi, 'Pengaruh Program Loyalitas terhadap Kesetiaan Konsumen pada Industri Halal di Yogyakarta', IHTIFAZ: Journal of Islamic Economics, Finance and Bank., vol. 1, no. 1, pp. 69-88, 2018.

[12] Fatmah, 'Pengaruh Persepsi Religiusitas, Kualitas Layanan, dan Inovasi Produk Terhadap Kepercayaan dan Komitmen serta Loyalitas Nasabah Bank Umum Syariah di Surabaya', Desertasi. Universitas Airlangga Surabaya, 2005.

[13] M. A. Khan, 'Pengaruh Religiusitas Dan Kepuasan Terhadap Loyalitas Nasabah Bank Syariah di Surabaya dengan Anteseden Kualitas Layanan', Tesis tidak dipublikasikan, Program Pasca Sarjana Magister Management, Sekolah Tinggi Ilmu Ekonomi Perbanas, Surabaya., 2015.

[14] S. N. . Prasetyo, 'Hubungan Antara Religiusitas dengan Loyalitas Nasabah pada Bank Syariah',Tesis tidak dipublikasikan. Universitas Muhammadiyah Malang. Malang, 2007.

[15] H. Wahyoedi, S. \& Winoto, 'Pengaruh Religiusitas, Kualitas Layanan, dan Trust Terhadap Loyalitas Nasabah Bank Syariah di Kota Bogor',Journal of Research ini Economics \& Management., vol. 17, pp. 189-198, 2017.

[16] R. Octavia, 'Pengaruh Kualitas Pelayanan dan Kepuasan Nasabah Terhadap Loyalitas Nasabah Tabungan Index Pada PT. Bank Index Kantor Cabang Lampung, Tesis Tidak Dipublikasikan, Program Pascasarjana Magister Manajemen Fakultas Ekonomi Dan Bisnis Universitas Lampung Banda', Universitas Lampung Bandar Lampung, 2016.

[17] M. Zakiy, 'Pengaruh Kualitas Layanan Terhadap Loyalitas Nasabah Bank Syariah Dengan Kepuasan Nasabah Sebagai Variabel Intervening', Jurnal Ekonomi dan Bisnis Islam, vol. 3, no. 1, p. 2017, 2017.

[18] B. Andreassen, T. W., Lindestad, 'Customer Loyalty and Complex Service: The Impact of Corporate Image on Quality, Customer Satisfaction and Loyalty for Customers with Varying Degrees of Service Expertises', International Journal of Services Industrial Management., vol. 9, no. 1, pp. 7-23, 1998.

[19] N. Mohsan, F., Nawas, M. M., Khan, S. M., Shaukat, Z., \& Aslam, 'Impact of Customer Stisfaction on Customer Loyalty and Intention to Switch: Evidence from Banking Sector of Pakistan', International Journal of Bussiness and Social Science., vol. 3, no. 2, pp. 1982-1991, 2011. 